Annals of Warsaw University of Life Sciences - SGGW

Land Reclamation No 43 (2), 2011: 185-192

(Ann. Warsaw Univ. of Life Sci. - SGGW, Land Reclam. 43 (2), 2011)

\title{
Assessment of permeability and pore water pressure in Warsaw clays based on in situ measurements
}

\author{
ZDZISŁAW SKUTNIK \\ Department of Geotechnical Engineering, Warsaw University of Life Sciences - SGGW
}

\begin{abstract}
Assessment of permeability and pore water pressure in Warsaw clays based on in situ measurements. The paper presents the results of groundwater monitoring program executed for the water intake at Stegny test site and for the deep foundation of the hotel building. It has been observed that during the excavation of massive in the Warsaw clays, the hydrostatic distribution of the pore water pressure do not remain constant, but changes into a new equilibrium groundwater flow regime. Negative pore water pressure (due to unloading) results in the increasing of effective stress within the clay subsoil for the short time conditions. Nevertheless observations and measurements confirmed the hydrostatic distribution of the pore water pressure for the long term conditions. This fact has to be taken into account for the estimation of the geotechnical parameters for the long term stability of the structure and the general safety.
\end{abstract}

Key words: Warsaw clays, effective stress, pore water pressure measurement.

\section{INTRODUCTION}

A wide program of in situ testing including the installation and observation of piezometers at the Stegny test site and on the hotel building site have been executed. Determination of the short term and long term pore water pressure distribution for the design and construction of the diaphragm walls and bottom slab of the hotel building was the main geotechnical problem. Time required to pass from undrained to drained conditions in relation to the rate of construction compared with the permeability of the clay allows estimating the stability of the diaphragm walls and bottom slab.

\section{INVESTIGATIONS AT THE STEGNY SITE}

The Stegny site is the place where for the last more then ten years a wide research program is executed by the Faculty of Geology of the Warsaw University, Faculty of Civil and Environmental Engineering of the Warsaw University of Life Sciences and other research institutions. The main purpose of these investigations is the estimation of the physical properties and mechanical parameters of the Pliocene clays. The experimental plot in Stegny (district of Warsaw) is located on a Quaternary flood terrace of the Vistula River.

From the surface down to the depth of $4.3 \mathrm{~m}$, occur dark-yellow homogeneous medium and fine sands. Within these sands, the groundwater level lies at the depth of $3.2 \mathrm{~m}$, beneath the sands, a complex of Tertiary clays has been found. The clay beds reveal a clear layered structure 
characterized by different colour of the particular layers.

In 1976 a borehole well was drilled in the Stegny site; it went down to $250 \mathrm{~m}$ and reached Oligocene deposits. During the drilling, piezometers were installed at different depths and from 1979 the pore water pressure is measured. The changes of the pore water pressure in the clay subsoil are presented in Figure 1. With time, the measured pore water pressure reach a hydrostatic distribution.

Many boreholes and CPT or CPTU soundings (Lunne et al. 1997) were per-

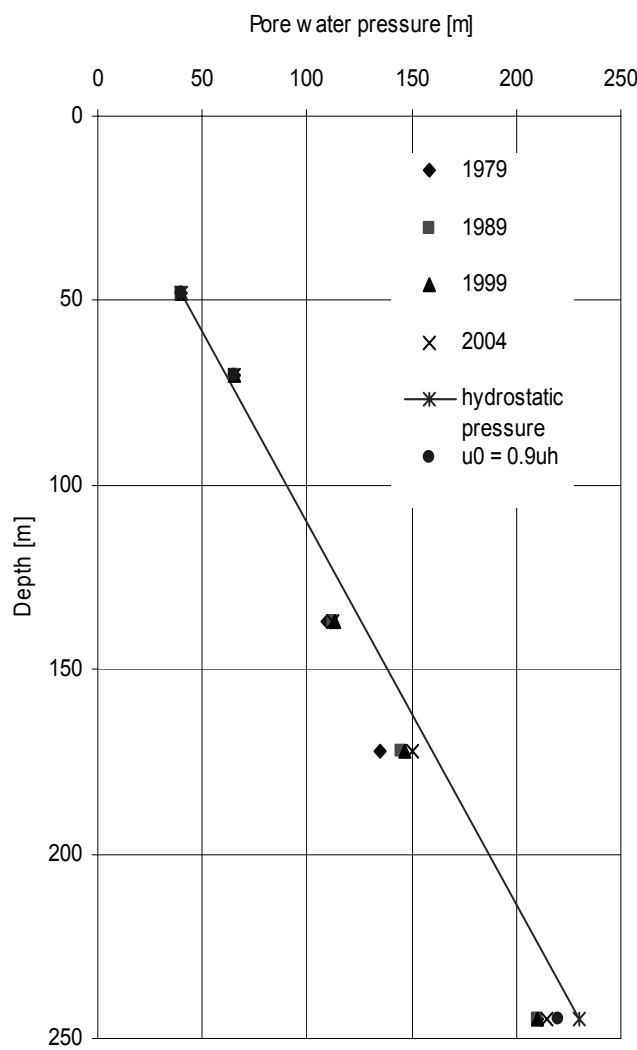

FIGURE 1. Changes of the pore water pressure with time in the clay subsoil of the borehole at the Stegny site formed on the site. Shelby samples were also taken from different depths. All the observations have confirmed that the Pliocene clays are not homogenous and clear distinction between a more silty or clayey subsoil was obtained. The typical results of the CPT test are presented in Figure 2.

Based on the results of the CPTU test it was decided where (at which depth) and

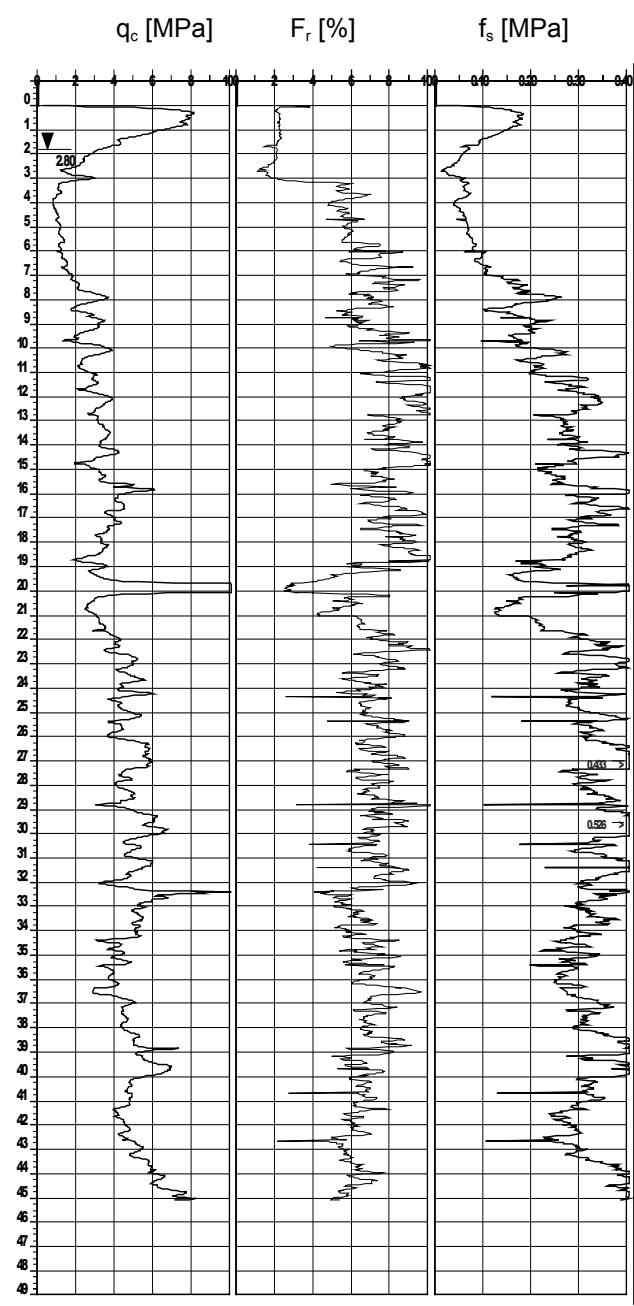

FIGURE 2. CPT test results at the Stegny site 
what type of device for pore water pressure measurements should be installed (Penman 1960). From the depth of $4 \mathrm{~m}$ below the ground surface to the depth of $35 \mathrm{~m}$, six piezometers of the Casagrande type, four BAT piezometers and tree electrical pore water pressure SISGEO transducers have been installed. The installation and next pressure monitoring in open and Casagrande piezometers, BAT

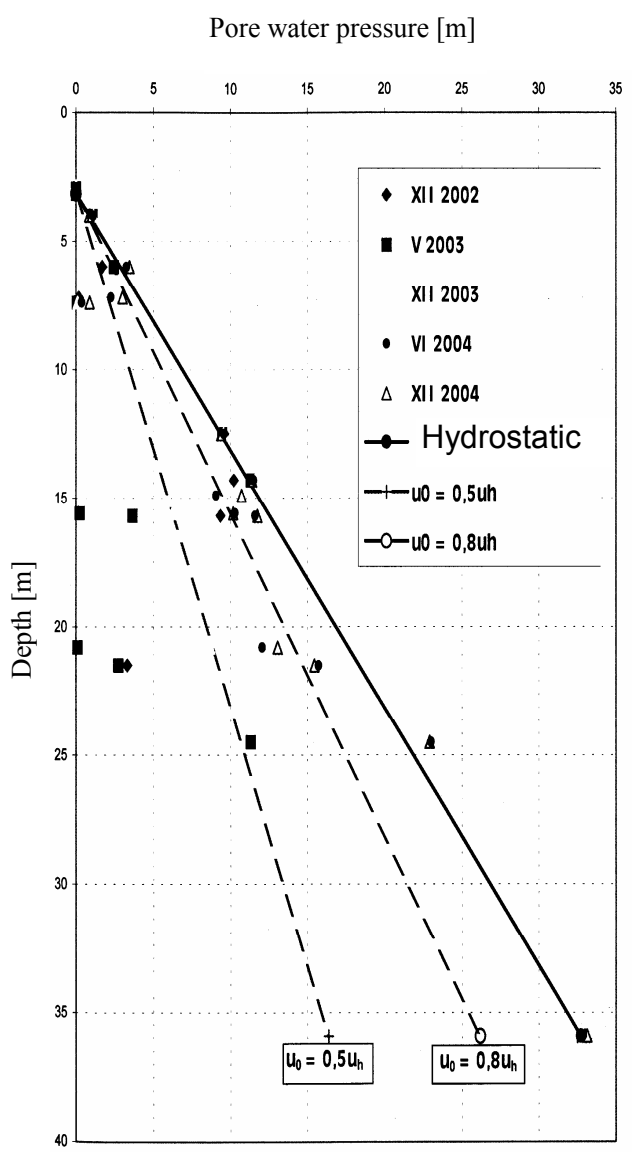

FIGURE 3. Changes of pore water pressures measured in piezometers installed in the clay subsoil at the Stegny site piezometers, electrical pore water pressure transducers have been identified as the main task during a wide program of in situ testing in the Stegny experimental site for the analysis of the Pliocene clay behavior in effective stress conditions.

Since 2000 till now the measurements of the pore water pressure are performed. The results of pore water pressure monitoring within the clay subsoil are presented in Figure 3.

It can be observed that the measured pore water is equalizing to hydrostatic pressure. The time of equalization depends on the permeability or presence or absence of cracks and interbeddings.

For estimation of the in situ flow parameters of clay deposits (horizontal coefficient of consolidation $\mathrm{c}_{\mathrm{h}}$ and hydraulic conductivity $\mathrm{k}_{\mathrm{h}}$ ) dissipation tests by DMTA methods (Marchetti and Totani 1989), CPTU dissipation tests and BAT tests (Torstensson 1984) were also performed at different depths. The coefficient of consolidation $\mathrm{c}_{\mathrm{h}}$ changes from $6.5 \times 10^{-9}$ to $1.3 \times 10^{-7} \mathrm{~m}^{2} / \mathrm{s}$ and the coefficient of hydraulic conductivity $\mathrm{k}_{\mathrm{h}}$ is less than $7 \times$ $\times 10^{-11} \mathrm{~m} / \mathrm{s}$.

For the estimation of the migration of groundwater in the clay subsoil the samples of water from different levels up to the depth of $35 \mathrm{~m}$ were collected. Geochemical analysis for the estimation of tritium content was performed. It allows estimating the time of groundwater standstill at a given depth. The results of chemical tests, values of tritium units (T.U.) and electrical conductivity of the groundwater from given depths are presented in Table 1. The shortest time of groundwater exchange is at the depth of $33 \mathrm{~m}$ below ground surface. 
TABLE 1. Tritium content T.U. and conductivity of water samples from the "Stegny" site (Skutnik et al. 2006)

\begin{tabular}{|c|c|c|c|c|c|c|}
\hline No & Borehole No & $\begin{array}{c}\text { Depth of } \\
\text { sample } \\
{[\mathrm{m}]}\end{array}$ & $\begin{array}{c}\text { Tritum con- } \\
\text { tent [T.U.] }\end{array}$ & $\begin{array}{c}\text { Instrumental } \\
\text { error }\end{array}$ & $\begin{array}{c}\text { Storage life } \\
{[\text { years] }}\end{array}$ & $\begin{array}{c}\text { Cunductivity } \\
{[\mathrm{mS} / \mathrm{cm}]}\end{array}$ \\
\hline 1 & ST0 & 4.0 & - & - & - & 0.640 \\
\hline 2 & OWIIIBC4 & 15.6 & - & - & - & 0.625 \\
\hline 3 & OWIIIA & 20.5 & 3.05 & \pm 0.12 & $50-55$ & 0.451 \\
\hline 4 & OWIIIA & 25.5 & 1.27 & \pm 0.27 & $>80$ & 0.530 \\
\hline 5 & OW IIIA & 33.0 & 6.59 & \pm 0.28 & $22-25$ & 0.384 \\
\hline 6 & $\begin{array}{c}\text { oligocene } \\
\text { water }\end{array}$ & 220.0 & - & - & - & 0.742 \\
\hline
\end{tabular}

\section{TESTS AT THE HOTEL BUILDING SITE}

From the geological point of view, the studied area lays within the Warsaw Basin, composed of Upper Cretaceous deposits, developed as marls and marly high plasticity clays, the top of which lies at approximately $250 \mathrm{~m}$ below ground level. The overlying Pliocene deposits are represented by clays as well as slimes interbedded with fine and silty sands. The thickness of the Pliocene deposits is variable and depends on the intensity of glacitectonical processes.

The geological cross-section of the hotel building subsoil is shown in Figure 4. The upper part of the subsoil consists of anthropogenic fill containing mineral soil of different grain size distribution; below fluvial deposits (from sand to gravel) were distinguished, in which the groundwater level lies at the depth of $6.0 \mathrm{~m}$ below ground surface (Wolski et al. 2003). Pliocene clays were encountered below the depth of 6 to $9 \mathrm{~m}$. According to geological data, the thickness of Pliocene clays in the area of the site equals to approximately $100 \mathrm{~m}$. The underground part of the building has been performed within diaphragm walls, in order to ensure the stability of the excavation both during the construction period and permanently after completion of the works. On the basis of geotechnical investigations (borings, CPT, DMT and BAT tests) the location and depth of piezometers installation have been specified (Fig. 5). The piezometers outside of the diaphragm wall foundation have been observed before and next during the construction period of more than two years. It was confirmed that the pore water pressures within the clay is equal or sometimes higher then groundwater level encountered in uper sand layer.

Six Casagrande piezometers below the foundation slab have been installed in three profiles (Fig. 5). The piezometers were installed at different depths below the foundation slab from $1.2 \mathrm{~m}$ to $4.8 \mathrm{~m}$ below the top of the clay subsoil (Fig. 6). The piezometers are observed till now (more than ten years) during the exploitation of the building. The results of the pore water measurements are presented in Figure 7.

The groundwater table at the site is located about $6 \mathrm{~m}$ below ground level. Therefore, the bottom of the excavation 


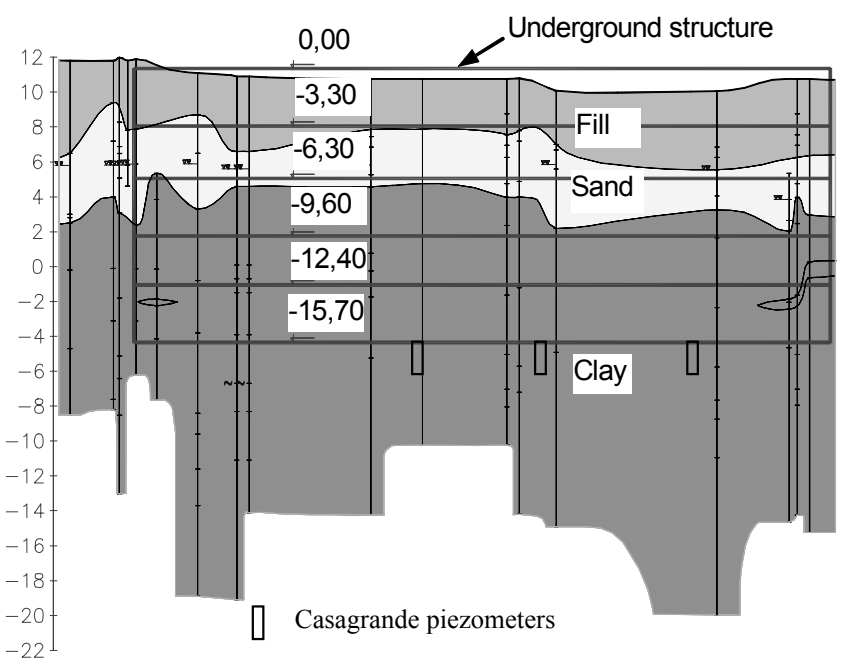

FIGURE 4. Geological cross-section of the hotel building subsoil

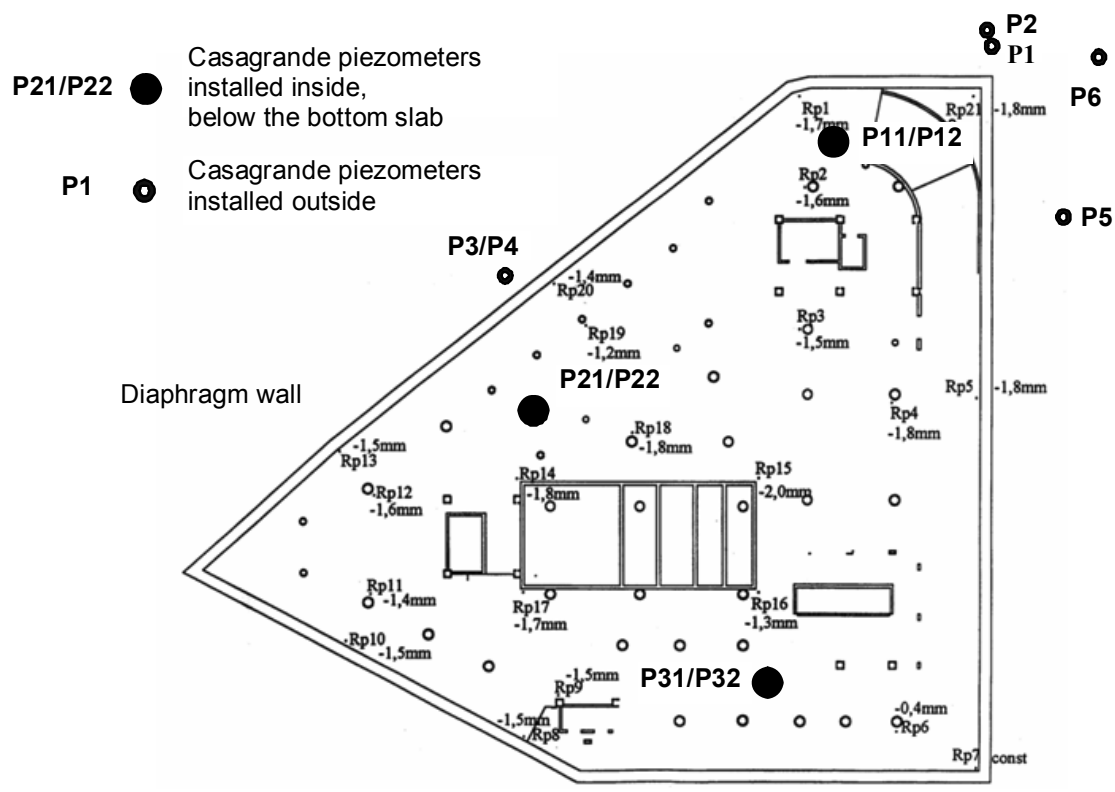

FIGURE 5. Location of piezometers installed outside and inside of the hotel building

is located at $15.7 \mathrm{~m}$ below the groundwater level, and thus a large difference in the hydraulic head was generated between the soil located outside (back of the diaphragm walls) and inside the excavation when the final excavation depth was reached. The main purpose of the installation of these piezometers was to control the pore water pressure within the clay subsoil and estimation of the 


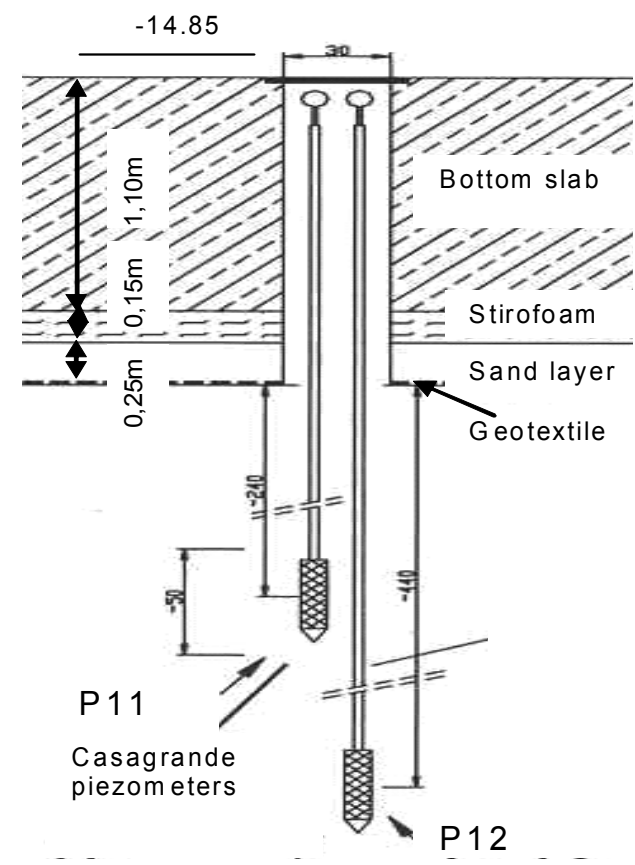

FIGURE 6. Scheme of the Casagrande piezometers installed below the bottom slab efficiency of the drainage system applied below the foundation slab.

The relatively high water level indicated by piezometers $\mathrm{P} 11, \mathrm{P} 12, \mathrm{P} 21$ and $\mathrm{P} 22$ (Fig. 7) confirmed the presence of more permeable soil layers within the area of the wells. The piezometer P31 is still dry while in P32 the small increase of pore water pressure was observed after five years. It is because they were installed within very homogenous clay, where no interbedings were encountered.

As a consequence, permanent seepage towards the bottom of the excavation was attained in long term. The time required to reach steady flow conditions depends on the permeability of the clay which is very low. It was confirmed by BAT permeability tests, which example of the results are presented in Figure 8.

The measured pore water pressures within the subsoil below the bottom foun-

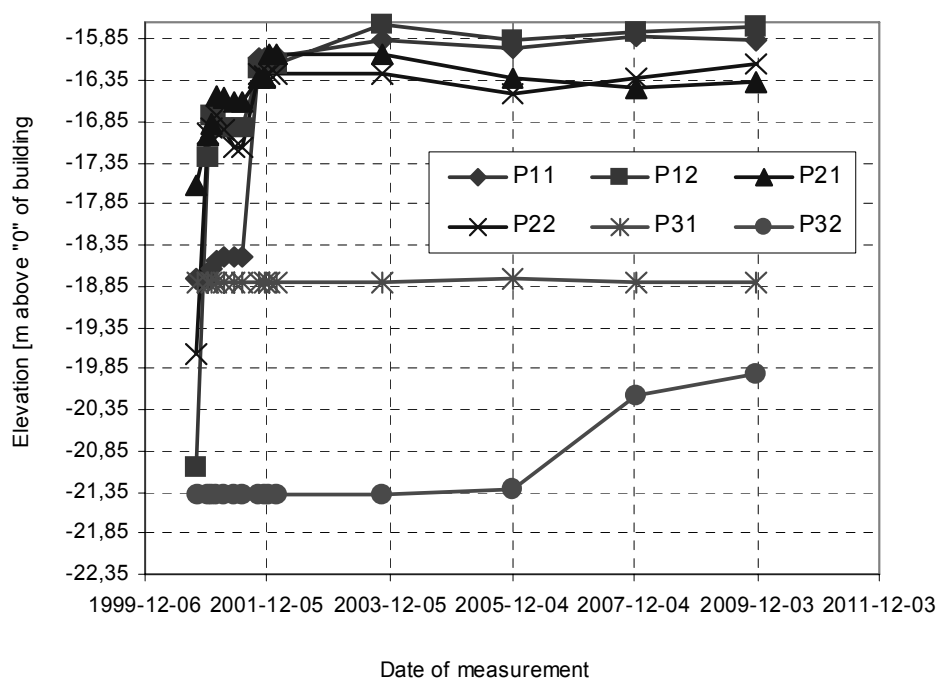

FIGURE 7. Pressures measured in the Casagrande piezometers installed below the bottom slab of the hotel building 


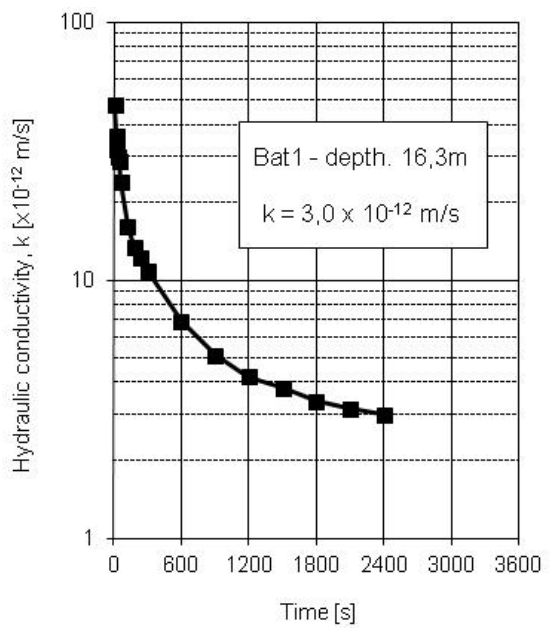

FIGURE 8. BAT permeability test results at hotel building clay subsoil

dation slab confirmed a necessity of the applied drainage system. The water pressure is about $10 \mathrm{~m}$ of water head lower then the water pressure measured outside of the building (diaphragm walls).

\section{CONCLUSIONS}

The results of piezometer observations and other test performed on the hotel building site and water intake site have confirmed the hydrostatic distribution of pore water pressure within the clay subsoil for long term conditions. This fact has to be taken into account for the estimation of the effective stress state conditions. The measured pore water pressures in the subsoil below the bottom foundation slab of the hotel building confirmed a relief of the drainage system.

Geotechnical problems related with the design of foundations and retaining walls in the clay subsoil are as follows: evaluation of the earth pressures in both undrained (short term) and drained (long term) conditions, evaluation of the effects of the construction rate compared to the permeability of the clay (time required to pass from undrained to drained conditions) and possible effects on the stability of the structure during construction.

\section{REFERENCES}

LUNNE T., ROBERTSON P.K., POWELL J.J.M. 1997: Cone penetration testing in geotechnical practice. Edts E \& FN SPON, London.

MARCHETTI S., TOTANI G. 1989: $\mathrm{C}_{\mathrm{h}}$ evaluation from DMTA dissipation curves. Proc. XII ICSMFE, Rio de Janeiro, Vol. 1, 281-286.

PENMAN A.D. 1960. Study of response times of various types piezometers. Proc. Conf. Pore Pressure and Suction in Soil, 53-58.

SKUTNIK Z., BOROWCZYK M., KRYSIAK S. 2006: Long term pore water pressure measurements for effective stress evaluation in Warsaw clays. Proc. XIII DECGE, Lubljana, 113-118.

TORSTENSSON B.A. 1984: A new system for Groundwater Monitoring System, Groundwater Monitoring Review, 131-138.

WOLSKI W., FÜRSTENBERG A., SORBJAN P., SKUTNIK Z. 2003: Wpływ warunków geotechnicznych na rozwiązania fundamentów hotelu Hyatt w Warszawie, Materiaty Budowlane $n r 3$ (in Polish).

Streszczenie: Ocena przepuszczalności $i$ ciśnienia wody w porach $w$ Itach Warszawskich na podstawie badan in situ. W artykule przedstawiono wyniki monitoringu wód podziemnych prowadzonego dla głębokiego fundamentu budynku hotelu oraz ujęcia wody oligoceńskiej w dzielnicy Stegny. Wyniki obserwacji wykazały, że podczas wykonywania wykopu fundamentowego w słaboprzepuszczalnych iłach plioceńskich, nazywanych w tym artykule Iłami Warszawskimi, ciśnienie wody w porach ulega zmianom, dążąc do stanu równowagi w nowych warunkach brzegowych. Ujemne ciśnienie wody w porach powstające na skutek odprężenia wykopem powodują krótkotrwały wzrost naprężenia efektywnego w podłożu. Niemniej jednak obserwacje i pomiary ciśnienia wody $\mathrm{w}$ porach iłów wykazują, że w warunkach długotrwałych ciśnienie dąży do rozkładu hydrostatycznego. Fakt ten należy uwzględniać 
przy wyznaczaniu parametrów geotechnicznych zarówno wytrzymałościowych, jak i odkształceniowych do oceny stateczności i bezpieczeństwa w warunkach długotrwałych.

Słowa kluczowe: Iły Warszawskie, naprężenie efektywne, pomiar ciśnienia wody w porach.

MS. received November 10, 2011
Author's address:

Zdzisław Skutnik

Katedra Geoinżynierii

Wydział Budownictwa i Inżynierii Środowiska Szkoła Główna Gospodarstwa Wiejskiego

Nowoursynowska 159

02-776 Warszawa

e-mail: zdzislaw_skutnik@sggw.pl

Poland 